\title{
2-Arylamino-4-Amino-5-Aroylthiazoles. "One-Pot” Synthesis and Biological Evaluation of a New Class of Inhibitors of Tubulin Polymerization
}

\author{
Romeo Romagnoli ${ }^{\star}, \dagger$, Pier Giovanni Baraldi ${ }^{*}, \dagger$, Maria Dora Carrion ${ }^{\dagger}$, Olga Cruz-Lopez $^{\dagger}$, \\ Carlota Lopez Cara ${ }^{\dagger}$, Giuseppe Basso $\ddagger$, Giampietro Viola ${ }^{\ddagger}$, Mohammed Khedrll, Jan \\ Balzarini $§$, Siavosh Mahboobi ${ }^{\perp}$, Andreas Sellmer ${ }^{\perp}$, Andrea Brancalell, and Ernest Hamel ${ }^{\#}$ \\ † Dipartimento di Scienze Farmaceutiche, Università di Ferrara, 44100 Ferrara, Italy \\ ‡ Dipartimento di Pediatria, Laboratorio di Oncoematologia, Università di Padova, 35131 Padova, \\ Italy \\ $\S$ Rega Institute for Medical Research, Laboratory of Virology and Chemotherapy, \\ Minderbroedersstraat 10, B-3000 Leuven, Belgium \\ II The Welsh School of Pharmacy, Cardiff University, King Edward VII Avenue, Cardiff CF10 3NB, \\ U.K \\ ${ }^{\perp}$ Faculty of Chemistry and Pharmacy, University of Regensburg, D-93040 Regensburg, Germany \\ \# Toxicology and Pharmacology Branch, Developmental Therapeutics Program, Division of Cancer \\ Treatment and Diagnosis, National Cancer Institute at Frederick, National Institutes of Health, \\ Frederick, Maryland 21702
}

\begin{abstract}
The essential role of microtubules in mitosis makes them a major target of compounds useful for cancer therapy. In our search for potent antitumor agents, a novel series of 2-anilino-4-amino-5aroylthiazoles was synthesized and evaluated for antiproliferative activity, inhibition of tubulin polymerization, and cell cycle effects. SAR was elucidated with various substitutions on the phenylamino and aroyl moiety at the 2- and 5-positions, respectively, of the 4-aminothiazole skeleton. Tumor cell exposure to several of these compounds led to the arrest of HeLa cells in the G2/M phase of the cell cycle and induction of apoptosis.
\end{abstract}

\section{Introduction}

There has been in recent years an intense effort in the discovery and development of novel small molecules, many of which are natural products, able to inhibit tubulin polymerization and have potential for the treatment of cancer. ${ }^{1,2}$ One of the most important antimitotic agents is combretastatin A-4 ${ }^{\mathrm{a}}$ (CA-4, 1; Chart 1). CA-4, isolated from the bark of the South African tree Combretumcaffrum ${ }^{3}$ is one of the well-known natural tubulin-binding molecules affecting microtubule dynamics by binding to the colchicine site. ${ }^{4}$ Replacement of the double bond

\footnotetext{
*To whom correspondence should be addressed. For R.R.: phone, 39-(0)532-455303; fax, 39-(0)532-455953; rmr@ unife.it. For P.G. B.: phone, 39-(0)532-455921; fax, 39-(0)532-455953; baraldi@unife.it.

Supporting Information Available: Detailed biological protocols, molecular modeling procedure, and spectroscopic data for compounds 5a-y. This material is available free of charge via the Internet at http://pubs.acs.org.

aAbbreviations: CA-4, combretastatin A-4; EWG, electron-withdrawing group; ERG, electron-releasing group; SAR, structure-activity relationships; $\mathrm{MeOH}$, methanol; $\mathrm{MeONa}$, sodium methoxide.
} 
ofCA-4 with a carbonyl group furnished a synthetic benzophenone-typeCA-4 analogue named phenstatin (2a), which demonstrated interesting efficacy in a variety of tumor models. ${ }^{5}$ The 2aminobenzophenone derivative $\mathbf{2 b}$ also strongly inhibited cancer cell growth and tubulin polymerization and caused mitotic arrest, as did $\mathbf{2 a} .^{6}$

The classical bioisosteric equivalence between benzene and thiophene prompted us recently to synthesize a series of 2-(3',4',5'-trimethoxybenzoyl)-3-amino-5-phenyl thiophene derivatives with general formula 3 , in which the thiophene system replaced the benzene moiety in the 2 -amino phenstatin analogue $\mathbf{2 a}$. $^{7}$ The analysis of structures of 2 -aminobenzophenone and 2-aroyl-3-aminothiophenes (compounds $\mathbf{2} \mathbf{b}$ and $\mathbf{3}$, respectively) showed that the ortho relationship between the aroyl group and the 2-amino moiety plays an essential role in activity.

Recently, investigators at Altana Pharma reported a series of [4-(imidazol-1-yl)thiazol-2-yl] phenylamine analogues with general structure $\mathbf{4}$, active at submicromolar concentrations as antiproliferative agents against human colon adenocarcinoma (RKOp27) cells and that act as inhibitors of microtubule polymerization by interfering with the colchicine site of tubulin. ${ }^{8}$

As a part of our search for novel antimitotic agents, these findings prompted us to synthesize a new series of 2-arylamino- 4-amino-5-aroylthiazole derivatives with general structure $\mathbf{5}$, obtained by incorporating the 3 -amino and 2-aroyl moieties of compounds with general structure 3 , into the 4- and 5-positions, respectively, of the 2-arylaminothiazole nucleus of general formula $4 .{ }^{9}$

While compounds 5a-f were characterized by the unsubstituted 5-benzoylthiazole structure, we also prepared several derivatives in which the methoxy group was placed at the para (5g$\mathbf{j}$ ), meta $(\mathbf{5 k}-\mathbf{l})$, or ortho $(\mathbf{5 m}-\mathbf{n})$ position on the B-phenyl ring of the 5-benzoyl moiety. To analyze the effect of additional methoxy groups, we synthesized the $3^{\prime}, 4^{\prime}$-dimethoxy benzoyl $(\mathbf{5 o}-\mathbf{p})$ and $3^{\prime}, 4^{\prime}, 5^{\prime}$-trimethoxybenzoyl (5q-v) analogues. Finally, to validate whether EWG's at the para-position of the B-ring can replace the methoxy group of compound $\mathbf{5 j}$ with retention of activity, we prepared the chloro (5w), bromo $(\mathbf{5 x})$, and nitro (5y) analogues. Once one, two, or three methoxy substituents were placed on the 5-benzoyl moiety, we explored SAR by examining various substitutions with electron-withdrawing $\left(\mathrm{F}, \mathrm{Cl}, \mathrm{Br}\right.$, and $\left.\mathrm{NO}_{2}\right)$ and electronreleasing ( $\mathrm{Me}$ and $\mathrm{MeO}$ ) groups on the A-phenyl ring of the 2-anilino moiety.

\section{Chemistry}

The 2-anilino-4-amino-5-aroyl thiazoles $\mathbf{5 a}-\mathbf{y}$ were synthesized in acceptable yield (35-55\%) by a one-pot, three-component reaction in $\mathrm{MeOH}$ of substituted phenyl isothiocyanates $6 \mathbf{a}-\mathbf{f}$ with $\alpha$-bromoketones 7a-l and cyanamide in a 1:1:1 ratio and in the presence of $\mathrm{MeONa}$ (in situ generated by methanol and sodium) as base (Scheme 1). ${ }^{10}$

\section{Results and Discussion}

The novel series of thiazole derivatives $\mathbf{5 a}-\mathbf{y}$ were evaluated for their antiproliferative activity against a panel of five tumor cell lines and compared with the reference compounds CA-4 (1) and 4a, as shown in Table 1. Of all the tested compounds, derivative $\mathbf{5 q}$ possessed the highest overall cytostatic potency, with $\mathrm{IC}_{50}$ values of $18,23,6,9$, and $14 \mathrm{nM}$ against the L1210, FM3A, Molt4, CEM, and HeLa cell lines, respectively. It had comparable or slightly greater antiproliferative activity than CA-4 against three cell lines and was less potent in two lines. Comparing derivatives $\mathbf{5 t}$ and $\mathbf{4 a}$, which shared a common 2-(p-methylanilino) thiazole moiety, $\mathbf{4 a}$ was from 40 - to 150 -fold less active than $\mathbf{5 t}$.

In comparing the effect of ERG's or EWG's at the para-position of the A-phenyl ring, compounds with electron-donating methyl or methoxy groups were generally more cytostatic 
than those with the electron-withdrawing fluoro or chloro moieties. In six of the eight potent analogues (i.e., 5l, 5n, 5p-q, and $\mathbf{5 w}-\mathbf{y}$ ), there was a para-methoxy substitution on the Aphenyl ring, and the only inactive compound with this substituent was $\mathbf{5 u}$, while $\mathbf{5 e}$ and $\mathbf{5 j}$ had weak activity. The presence of the para-methoxy group in the A ring allowed a wide range of substituents in the B ring (meta- and ortho-methoxy groups in $\mathbf{5} \mathbf{l}$ and $\mathbf{5 n}$, respectively; parachloro, -bromo, and -nitro groups in $\mathbf{5 w}, \mathbf{5 x}$, and $\mathbf{5 y}$, respectively; and even a meta-, paradimethoxy substitution in $\mathbf{5 p}$ ), but neither a bare B ring as in $\mathbf{5 e}$, a $4^{\prime}$-methoxy group as in $\mathbf{5 j}$, nor the $3^{\prime}, 4^{\prime}, 5^{\prime}$-trimethoxy substitution pattern of $5 \mathbf{u}$ were tolerated. However, the $3^{\prime}, 4^{\prime}, 5^{\prime}-$ trimethoxy substitution pattern was tolerated with either no A ring substituent (the highly active $\mathbf{5 q})$ or the smaller A ring methyl substituent of $\mathbf{5 t}$.

The results also showed that, with the notable exception of $\mathbf{5 q}$, all compounds with no substituent in either ring A or ring B had minimal or reduced antiproliferative activity (5a-g, $\mathbf{5 k}, \mathbf{5 m}$, and 5o). Again, with the exception of $\mathbf{5 q}$, the data showed that the ring B para-position is the least favorable for a methoxy group. However, para B ring EWG's are also associated with high antiproliferative activity when a para-methoxy-substituted A ring is also present $(\mathbf{5 w}-\mathbf{y})$.

In the series of $3^{\prime}, 4^{\prime}, 5^{\prime}$-trimethoxybenzoyl thiazole derivatives $\mathbf{5 q}-\mathbf{v}$, the unsubstituted 2phenylamino derivative $\mathbf{5 q}$ was the most active inhibitor of cell growth. Introduction of a fluorine (5r) or chlorine (5s) into the ortho-position of A-phenyl ring caused on average a 27fold reduction of potency relative to $\mathbf{5 q}$, while the para-methyl compound $\mathbf{5 t}$ was almost as active as $\mathbf{5 q}$. The replacement of the para-methyl with a para-methoxy (5u), as noted above, was highly detrimental to activity, resulting, on average, in an 83-fold reduction of potency. The compound with a meta-methoxy group (5v) was similarly inactive.

As noted above, ERG's are not indispensable on the B-ring, as shown by the activity of derivatives $\mathbf{5 w}-\mathbf{y}$. In fact, in the para-position EWG's resulted in compounds $(\mathbf{5} \mathbf{w}-\mathbf{y})$ with substantially more cytostatic activity than was observed with the para-methoxy group of compound $\mathbf{5 j}$.

To investigate whether the antiproliferative activities of this novel series of 4-aminothiazole derivatives involved an interaction with tubulin, a selected series of compounds $(\mathbf{5 a}, \mathbf{5 f}, \mathbf{5 1}$, $\mathbf{5 n}, \mathbf{5 p}-\mathbf{q}, \mathbf{5 t}$, and $\mathbf{5 w}$ ) were evaluated for their in vitro inhibition of tubulin polymerization and for their inhibitory effects on the binding of $\left[{ }^{3} \mathrm{H}\right]$ colchicine to tubulin (Table 2). For comparison, CA-4 and 4a were examined in contemporaneous experiments. In the assembly assay, compound $\mathbf{5 t}$ was found to be the most active $\left(\mathrm{IC}_{50}, 0.72 \mu \mathrm{M}\right)$ and it was 2- and 5-times more potent than CA-4 and $\mathbf{4 a}$ (IC $\mathrm{IC}_{50}$ 's of 1.4 and $4.0 \mu \mathrm{M}$, respectively). Derivatives $\mathbf{5 l}, \mathbf{5 n}$, and $\mathbf{5 w}$ had activity comparable to that of CA-4, while $\mathbf{5 p}$ and $\mathbf{5 q}$ were about half as potent as CA-4. Unexpectedly, derivatives $\mathbf{5 a}$ and $\mathbf{5 f}$ were 5- and 10-fold less active than $\mathbf{5 t}$ as inhibitors of tubulin assembly although they were 2 orders of magnitude less potent in their effects on cell growth. The reduced antiproliferative activities of $\mathbf{5 a}$ and $\mathbf{5 f}$ may result from poor permeability into cells, poor solubility in the tissue culture medium, or any other mechanism limiting the accessibility of these molecules to cellular tubulin. Alternatively, these molecules may be exerting their effect by a different, as yet uncovered, mechanism of action.

For these eight compounds, $\mathbf{4 a}$ and CA-4, the order of activity as inhibitors of tubulin assembly was $\mathbf{5 t}>\mathbf{5 w}>\mathrm{CA}-4=\mathbf{5 l}=\mathbf{5 n}>\mathbf{5 q}>\mathbf{5 p}>\mathbf{5 f}>\mathbf{4 a} \gg \mathbf{5 a}$. The potent activity of derivatives $\mathbf{5 l}, \mathbf{5 n}$, and $\mathbf{5 w}$ showed that the $3^{\prime}, 4^{\prime}, 5^{\prime}$-trimethoxybenzoyl group was not necessary for inhibiting tubulin assembly.

In the colchicine binding studies, derivatives $\mathbf{5 l}, \mathbf{5 t}$, and $\mathbf{5 w}$ were as potent as CA-4, which in these experiments inhibited colchicine binding by $87 \%$. In general, inhibition of $\left[{ }^{3} \mathrm{H}\right]$ colchicine 
binding to tubulin correlated more closely with antiproliferative activity than inhibition of tubulin assembly.

The effects of compounds $\mathbf{5 l}, \mathbf{5 n}, \mathbf{5 p}-\mathbf{q}, \mathbf{5 t}$, and $\mathbf{5 w}$ on the cell cycle were examined by flow cytometry after staining the cells with propidium iodide. HeLa cells were exposed for $24 \mathrm{~h}$ to different concentrations of the compounds. All tested compounds (see Figure 1 in the Supporting Information) caused an evident and rapid increase of cells in the G2-M phase, and this was already significant for all compounds at a concentration of $30 \mathrm{nM}$. Aconcomitant decrease of cells in the G1 and S phases was also observed. All the compounds also caused the appearance of a hypodiploid peak (sub-G1), indicative of apoptosis (see Figure 2 in the Supporting Information). Compared with the sub-G1 area (8.9\%) in control cells, all compounds (except 5l) showed a significant increase in apoptotic cells in a concentrationdependent manner (see Figure 3 in the Supporting Information).

We also performed a series of molecular docking simulations in the colchicine site of tubulin with the most active compound $\mathbf{5 t} .{ }^{11}$ The proposed binding of this compound is shown in Figure 1 , and it is possible to see how the trimethoxyphenyl moiety is placed in proximity of Cys 241 (residue numbering based on the crystal structure used). Furthermore, binding is stabilized by the presence of three hydrogen bonds between the thiazole core and Thr179, Ser178, and Thr353. These residues (Cys241, Thr179, and Ser178) were also found to be involved in the binding of other tubulin binding agents. ${ }^{12}$ Finally, the aromatic ring in position 2 of the thiazole is on the edge of the binding pocket.

In conclusion, we have discovered a new class of structurally simple synthetic inhibitors of tubulin polymerization based on a 2-anilino-4-amino-5-aroylthiazole molecular skeleton. With the exception of $3^{\prime}, 4^{\prime}, 5^{\prime}$-trimethoxybenzoyl derivatives $\mathbf{5 u}-\mathbf{v}$, we found that ERG's on the Aphenyl ring enhanced antiproliferative activity, while EWG's reduced antiproliferative activity. By comparing the effects of ERG's and EWG's on the B-phenyl ring, compounds (i.e., 5j, 5w, 5x, and $\mathbf{5 y}$ ) with substituents with opposite electronic effects showed similar potency. We also showed by flow cytometry that selected compounds had cellular effects typical for microtubule- interacting agents, causing accumulation of apoptotic cells and cells in the $\mathrm{G} 2 / \mathrm{M}$ phase of the cell cycle. The preparation of these compounds was carried out via an efficient procedure, and they constitute an interesting class of potent antitubulin agents which will be further evaluated as potential anticancer agents.

\section{Experimental Section}

\section{General Procedure for the Synthesis of Compounds 5a-y}

Sodium (188 mg, $8.2 \mathrm{mmol})$ was carefully dissolved in $\mathrm{MeOH}(10 \mathrm{~mL})$ at ambient temperature. The resultant solution was added dropwise, over $10 \mathrm{~min}$, to a mixture of cyanamide ( $345 \mathrm{mg}$, $8.2 \mathrm{mmol})$ and arylisothiocyanate $(8.2 \mathrm{mmol}, 1$ equiv) dissolved in $\mathrm{MeOH}(5 \mathrm{~mL})$, and cooled with an ice-bath. The appropriate phenacyl bromide $(8.2 \mathrm{mmol}, 1$ equiv) was added in small portions, and the resulting mixture was stirred overnight at ambient temperature. The mixture was diluted with water $(10 \mathrm{~mL})$ and extracted with dichloromethane $(3 \times 15 \mathrm{~mL})$. The organic phase was washed with brine $(10 \mathrm{~mL})$, dried over $\mathrm{Na}_{2} \mathrm{SO}_{4}$, and evaporated. The residue was purified by silica gel column chromatography or crystallized from ethyl ether or petroleum ether.

\section{Supplementary Material}

Refer to Web version on PubMed Central for supplementary material. 


\section{Acknowledgments}

We wish to thank Alberto Casolari for technical assistance.

\section{References}

1. Amos LA. Microtubule structure and its stabilisation. Org Biomol Chem 2004;2:2153-2160. [PubMed: 15280946]

2. Mahindroo N, Liou JP, Chang JY, Hsieh HP. Antitubulin agents for the treatment of cancer. A medicinal chemistry update. Exp Opin Ther Pat 2006;16:647-691.

3. Pettit GR, Singh SB, Hamel E, Lin CM, Alberts DS, Garcia-Kendall D. Isolation and structure of the strong cell growth and tubulin inhibitor combretastatin A-4. Experientia 1989;45:209-211. [PubMed: 2920809]

4. Lin CM, Ho HH, Pettit GR, Hamel E. Antimitotic natural products combretastatin A-4 and combretastatin A-2: studies on the mechanism of their inhibition of the binding of colchicine to tubulin. Biochemistry 1989;28:6984-6991. [PubMed: 2819042]

5. Pettit GR, Toki B, Herald DL, Verdier-Pinard P, Boyd MR, Hamel E, Pettit RK. Antineoplastic agents. 379. Synthesis of phenstatin phosphate. J Med Chem 1998;41:1688-1695. [PubMed: 9572894]

6. Liou JP, Chang CW, Song JW, Yang YN, Yeh CF, Tseng HY, Lo YK, Chang YL, Chang CM, Hsieh HP. Synthesis and structure-activity relationship of 2-aminobenzophenone derivatives as antimitotic agents. J Med Chem 2002;45:2556-2572. [PubMed: 12036364]

7. Romagnoli R, Baraldi PG, Remusat V, Carrion MD, Lopez Cara C, Preti D, Fruttarolo F, Pavani MG, Tabrizi MA, Tolomeo M, Grimaudo S, Balzarini J, Jordan MA, Hamel E. Synthesis and biological evaluation of 2-(3',4',5'-trimethoxybenzoyl)-3-amino 5-aryl thiophenes as a new class of tubulin inhibitors. J Med Chem 2006;49:6425-6428. [PubMed: 17034150]

8. Mahboobi S, Sellemer A, Hocher H, Eichhorn E, Bar T, Schmidt M, Maier T, Stadlweiser JF, Beckers TL. [4-(Imidazol-1-yl)thiazol-2-yl]phenylamines. A novel class of highly potent colchicine site binding tubulin inhibitors: synthesis and cytotoxic activity on selected human cancer cell lines. J Med Chem 2006;49:5769-5776. [PubMed: 16970401]

9. Only one compound of this series (5e) was reported in literature and showed an $\mathrm{IC}_{50}$ average value of $0.35 \mu \mathrm{M}$ against different cancer cell lines. Sengupta S, Smitha SL, Thomas NE, Santhoshkumar TR, Devi KC, Sreejaleksmi KG, Rajasekharan KN. 4-Amino-5-benzoyl-2-(4-methoxyphenylamino) thiazole (DAT1): a cytotoxic agent towards cancer cells and a probe for tubulin-microtubule system. Br J Pharmacol 2005;145:1076-1083. [PubMed: 15951833]

10. Gewald K, Blauschmidt P, Mayer P. 4-Amino-thiazole. J Prakt Chem 1967;35:97-104.

11. Ravelli RBG, Gigant B, Curmi PA, Jourdain I, Lachkar S, Sobel A, Knossow M. Insight into tubulin regulation from a complex with colchicine and a stathmin-like domain. Nature 2004;428:198-202. [PubMed: 15014504]

12. De Martino G, Edler MC, La Regina G, Coluccia A, Barbera MC, Barrow D, Nicholson RI, Chiosis G, Brancale A, Hamel E, Artico M, Silvestri R. Arylthioindoles, potent inhibitors of tubulin polymerization. 2. Structure-activity relationships and molecular modeling studies. J Med Chem 2006;49:947-954. [PubMed: 16451061] 


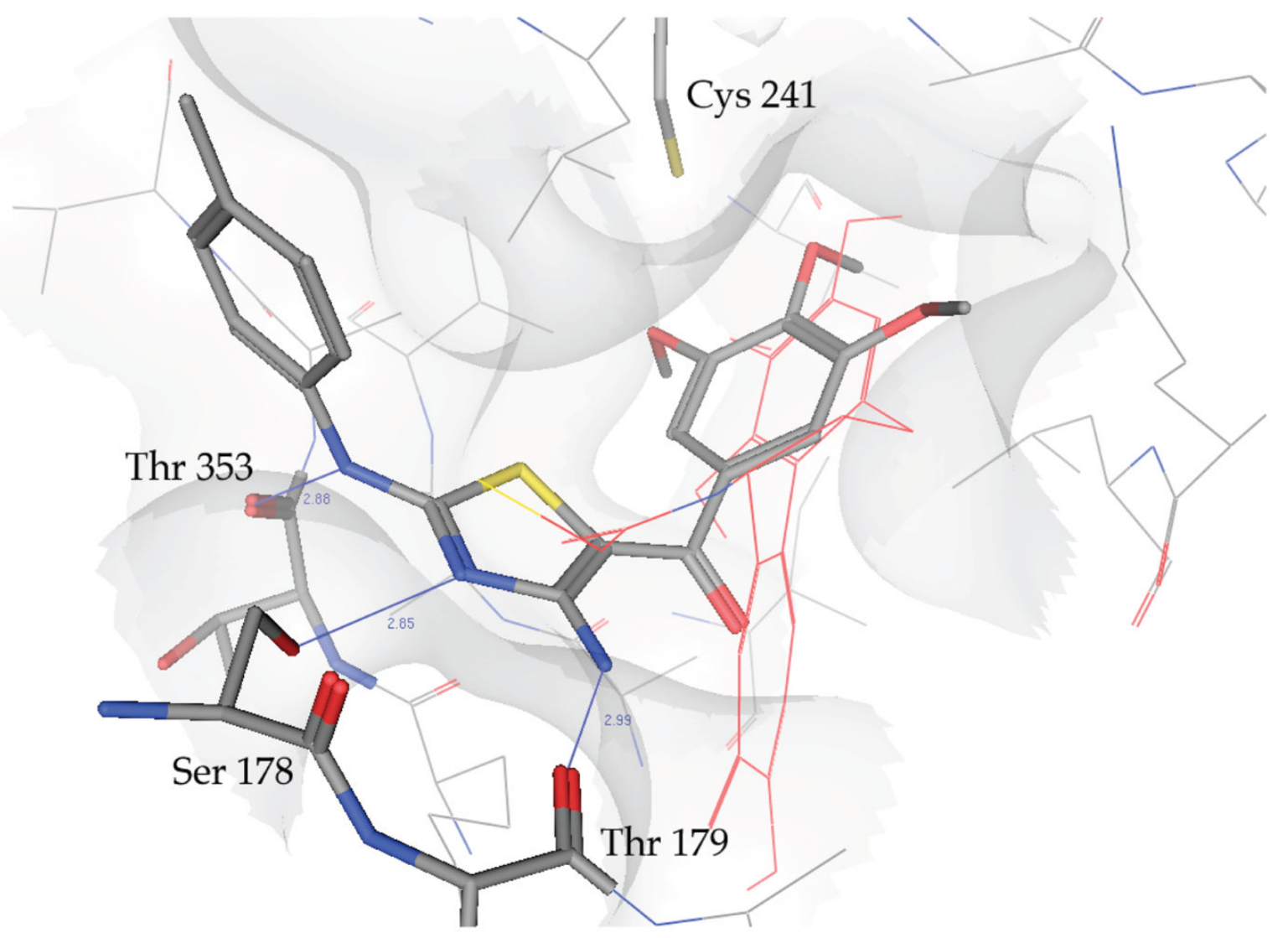

Figure 1.

Proposed binding mode of $\mathbf{5 t}$ in the colchicine site. DAMA-colchicine in red. 


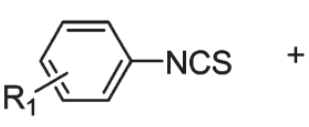

6a-e<smiles>O=C(CBr)c1ccccc1</smiles>
6a, $\mathrm{R}_{1}=\mathrm{H}$
6b, $R_{1}=p-F$
6c, $\mathrm{R}_{1}=\mathrm{p}-\mathrm{Cl}$
6d, $\mathrm{R}_{1}=\mathrm{p}-\mathrm{CH}_{3}$
6e, $\mathrm{R}_{1}=\mathrm{p}-\mathrm{OCH}_{3}$
6f, $\mathrm{R}_{1}=\mathrm{m}-\mathrm{OCH}_{3}$

$7 a, \mathrm{R}_{1}=\mathrm{H}$

$7 \mathrm{~b}, \mathrm{R}_{1}=\mathrm{p}-\mathrm{OCH}_{3}$

7c, $\mathrm{R}_{1}=\mathrm{m}-\mathrm{OCH}_{3}$

7d, $\mathrm{R}_{1}=\mathrm{O}-\mathrm{OCH}_{3}$

7e, $\mathrm{R}_{1}=\mathrm{m}, \mathrm{p}-\left(\mathrm{OCH}_{3}\right)_{2}$

7f, $\mathrm{R}_{1}=\mathrm{m}, \mathrm{m}^{\prime}, \mathrm{p}-\left(\mathrm{OCH}_{3}\right)_{3}$

$7 \mathrm{~g}, \mathrm{R}_{1}=\mathrm{p}-\mathrm{Cl}$

$7 \mathrm{~h}, \mathrm{R}_{1}=\mathrm{p}-\mathrm{Br}$

7i, $\mathrm{R}_{1}=\mathrm{p}-\mathrm{NO}_{2}$<smiles>[R][R]c1cccc(C(=O)c2sc(Nc3cccc(C)c3)nc2N)c1</smiles>

5a, $\mathrm{R}_{1}=\mathrm{R}_{2}=\mathrm{H}$

5b, $\mathrm{R}_{1}=\mathrm{p}-\mathrm{F}, \mathrm{R}_{2}=\mathrm{H}$

5c, $\mathrm{R}_{1}=\mathrm{p}-\mathrm{Cl}, \mathrm{R}_{2}=\mathrm{H}$

5d, $\mathrm{R}_{1}=\mathrm{p}-\mathrm{CH}_{3}, \mathrm{R}_{2}=\mathrm{H}$

5e, $\mathrm{R}_{1}=\mathrm{p}-\mathrm{OCH}_{3}, \mathrm{R}_{2}=\mathrm{H}$

5f, $\mathrm{R}_{1}=\mathrm{m}-\mathrm{OCH}_{3}, \mathrm{R}_{2}=\mathrm{H}$

5g, $\mathrm{R}_{1}=\mathrm{H}, \mathrm{R}_{2}=\mathrm{p}-\mathrm{OCH}_{3}$

5h, $\mathrm{R}_{1}=\mathrm{p}-\mathrm{F}, \mathrm{R}_{2}=\mathrm{p}-\mathrm{OCH}_{3}$

5i, $\mathrm{R}_{1}=\mathrm{p}-\mathrm{Cl}, \mathrm{R}_{2}=\mathrm{p}-\mathrm{OCH}_{3}$

5j, $\mathrm{R}_{1}=\mathrm{R}_{2}=\mathrm{p}-\mathrm{OCH}_{3}$

5k, $\mathrm{R}_{1}=\mathrm{H}, \mathrm{R}_{2}=\mathrm{m}-\mathrm{OCH}_{3}$

5I, $\mathrm{R}_{1}=\mathrm{p}-\mathrm{OCH}_{3}, \mathrm{R}_{2}=\mathrm{m}-\mathrm{OCH}_{3}$

$5 \mathrm{~m}, \mathrm{R}_{1}=\mathrm{H}, \mathrm{R}_{2}=\mathrm{O}-\mathrm{OCH}_{3}$

5n, $\mathrm{R}_{1}=\mathrm{p}-\mathrm{OCH}_{3}, \mathrm{R}_{2}=\mathrm{O}-\mathrm{OCH}_{3}$

5o, $\mathrm{R}_{1}=\mathrm{H}, \mathrm{R}_{2}=\mathrm{m}, \mathrm{p}-\left(\mathrm{OCH}_{3}\right)_{2}$

5p, $\mathrm{R}_{1}=\mathrm{p}-\mathrm{OCH}_{3}, \mathrm{R}_{2}=\mathrm{m}, \mathrm{p}-\left(\mathrm{OCH}_{3}\right)_{2}$

5q, $\mathrm{R}_{1}=\mathrm{H}, \mathrm{R}_{2}=\mathrm{m}, \mathrm{m}^{\prime}, \mathrm{p}-\left(\mathrm{OCH}_{3}\right)_{3}$

5r, $\mathrm{R}_{1}=\mathrm{p}-\mathrm{F}, \mathrm{R}_{2}=\mathrm{m}, \mathrm{m}^{\prime}, \mathrm{p}-\left(\mathrm{OCH}_{3}\right)_{3}$

5s, $\mathrm{R}_{1}=\mathrm{p}-\mathrm{Cl}, \mathrm{R}_{2}=\mathrm{m}, \mathrm{m}^{\prime}, \mathrm{p}-\left(\mathrm{OCH}_{3}\right)_{3}$

5t, $\mathrm{R}_{1}=\mathrm{p}-\mathrm{CH}_{3}, \mathrm{R}_{2}=\mathrm{m}, \mathrm{m}^{\prime}, \mathrm{p}-\left(\mathrm{OCH}_{3}\right)_{3}$

5u, $\mathrm{R}_{1}=\mathrm{p}-\mathrm{OCH}_{3}, \mathrm{R}_{2}=\mathrm{m}, \mathrm{m}^{\prime}, \mathrm{p}-\left(\mathrm{OCH}_{3}\right)_{3}$

$5 v, \mathrm{R}_{1}=\mathrm{m}-\mathrm{OCH}_{3}, \mathrm{R}_{2}=\mathrm{m}, \mathrm{m}^{\prime}, \mathrm{p}-\left(\mathrm{OCH}_{3}\right)_{3}$

$5 \mathrm{w}, \mathrm{R}_{1}=\mathrm{p}-\mathrm{OCH}_{3}, \mathrm{R}_{2}=\mathrm{p}-\mathrm{Cl}$

5x, $\mathrm{R}_{1}=\mathrm{p}-\mathrm{OCH}_{3}, \mathrm{R}_{2}=\mathrm{p}-\mathrm{Br}$

5y, $\mathrm{R}_{1}=\mathrm{p}-\mathrm{OCH}_{3}, \mathrm{R}_{2}=\mathrm{p}-\mathrm{NO}_{2}$

Scheme 1a.

a Reagents: (a) $\mathrm{NH}_{2} \mathrm{CN}, \mathrm{Na}, \mathrm{MeOH}$, rt. 
<smiles>COc1ccc(/C=C\c2cc(OC)c(OC)c(OC)c2)cc1O</smiles>

Combretastatin A-4 (CA-4), 1<smiles>[R]=CC=C(c1cc#[R]cc1)c1cc(N)c(C(=O)c2cc(OC)c(OC)c(OC)c2)s1</smiles>

$\mathrm{R}=\mathrm{H}$, halogen, $\mathrm{CH}_{3}$, $\mathrm{CF}_{3}, \mathrm{MeO}$

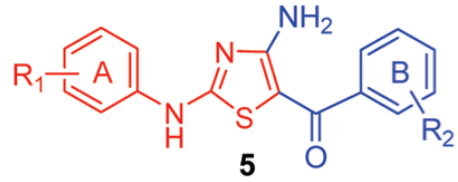<smiles>[R]c1c(OC)ccc(C(=O)c2cc(O)c(OC)c(OC)c2)c1[R]</smiles>

$\mathrm{R}_{1}=\mathrm{H}, \mathrm{R}_{2}=\mathrm{OH}$, Phenstatin, 2a $\mathrm{R}_{1}=\mathrm{NH}_{2}, \mathrm{R}_{2}=\mathrm{H}, \mathbf{2 b}$<smiles>[R7]c1cccc(Nc2nc(-n3cc([R3])nc3[R])cs2)c1</smiles>

$\mathrm{R}_{1}=\mathrm{H}, \mathrm{Br}, \mathrm{Me}$ or $\mathrm{OMe}$

$\mathrm{R}_{2}$ and $\mathrm{R}_{3}=\mathrm{H}$ or $\mathrm{Me}$

$4 a, R_{1}=p-M e, R_{2}=M e, R_{3}=H$

5a, $\mathrm{R}_{1}=\mathrm{R}_{2}=\mathrm{H}$

5b, $\mathrm{R}_{1}=\mathrm{p}-\mathrm{F}, \mathrm{R}_{2}=\mathrm{H}$

5c, $\mathrm{R}_{1}=\mathrm{p}-\mathrm{Cl}, \mathrm{R}_{2}=\mathrm{H}$

5d, $\mathrm{R}_{1}=\mathrm{p}-\mathrm{CH}_{3}, \mathrm{R}_{2}=\mathrm{H}$

5e, $\mathrm{R}_{1}=\mathrm{p}-\mathrm{OCH}_{3}, \mathrm{R}_{2}=\mathrm{H}$

5f, $\mathrm{R}_{1}=\mathrm{m}-\mathrm{OCH}_{3}, \mathrm{R}_{2}=\mathrm{H}$

5g, $\mathrm{R}_{1}=\mathrm{H}, \mathrm{R}_{2}=\mathrm{p}-\mathrm{OCH}_{3}$

5h, $R_{1}=p-F, R_{2}=p-O_{3}$

5i, $\mathrm{R}_{1}=\mathrm{p}-\mathrm{Cl}, \mathrm{R}_{2}=\mathrm{p}-\mathrm{OCH}_{3}$

5j, $\mathrm{R}_{1}=\mathrm{R}_{2}=\mathrm{p}-\mathrm{OCH}_{3}$

5k, $\mathrm{R}_{1}=\mathrm{H}, \mathrm{R}_{2}=\mathrm{m}-\mathrm{OCH}_{3}$

5I, $\mathrm{R}_{1}=\mathrm{p}-\mathrm{OCH}_{3}, \mathrm{R}_{2}=\mathrm{m}-\mathrm{OCH}_{3}$

$5 \mathrm{~m}, \mathrm{R}_{1}=\mathrm{H}, \mathrm{R}_{2}=\mathrm{O}-\mathrm{OCH}_{3}$

5n, $\mathrm{R}_{1}=\mathrm{p}-\mathrm{OCH}_{3}, \mathrm{R}_{2}=\mathrm{o}-\mathrm{OCH}_{3}$

5o, $\mathrm{R}_{1}=\mathrm{H}, \mathrm{R}_{2}=\mathrm{m}, \mathrm{p}-\left(\mathrm{OCH}_{3}\right)_{2}$

$5 p, R_{1}=p-O_{3}, R_{2}=m, p-\left(\mathrm{OCH}_{3}\right)_{2}$

5q, $\mathrm{R}_{1}=\mathrm{H}, \mathrm{R}_{2}=\mathrm{m}, \mathrm{m}^{\prime}, \mathrm{p}-\left(\mathrm{OCH}_{3}\right)_{3}$

5r, $R_{1}=p-F, R_{2}=m, m^{\prime}, p-\left(\mathrm{OCH}_{3}\right)_{3}$

5s, $\mathrm{R}_{1}=\mathrm{p}-\mathrm{Cl}, \mathrm{R}_{2}=\mathrm{m}, \mathrm{m}^{\prime}, \mathrm{p}-\left(\mathrm{OCH}_{3}\right)_{3}$

5t, $\mathrm{R}_{1}=\mathrm{p}-\mathrm{CH}_{3}, \mathrm{R}_{2}=\mathrm{m}, \mathrm{m}^{\prime}, \mathrm{p}-\left(\mathrm{OCH}_{3}\right)_{3}$

5u, $\mathrm{R}_{1}=\mathrm{p}-\mathrm{OCH}_{3}, \mathrm{R}_{2}=\mathrm{m}, \mathrm{m}$ ', p- $\left(\mathrm{OCH}_{3}\right)_{3}$

5v, $\mathrm{R}_{1}=\mathrm{m}-\mathrm{OCH}_{3}, \mathrm{R}_{2}=\mathrm{m}, \mathrm{m}^{\prime}, \mathrm{p}-\left(\mathrm{OCH}_{3}\right)_{3}$

$5 w, R_{1}=p-O_{3}, R_{2}=p-C l$

$5 x, R_{1}=p-\mathrm{OCH}_{3}, \mathrm{R}_{2}=p-\mathrm{Br}$

$5 y, R_{1}=p-O_{3}, R_{2}=p-N_{2}$

Chart 1.

Inhibitors of Tubulin Polymerization 


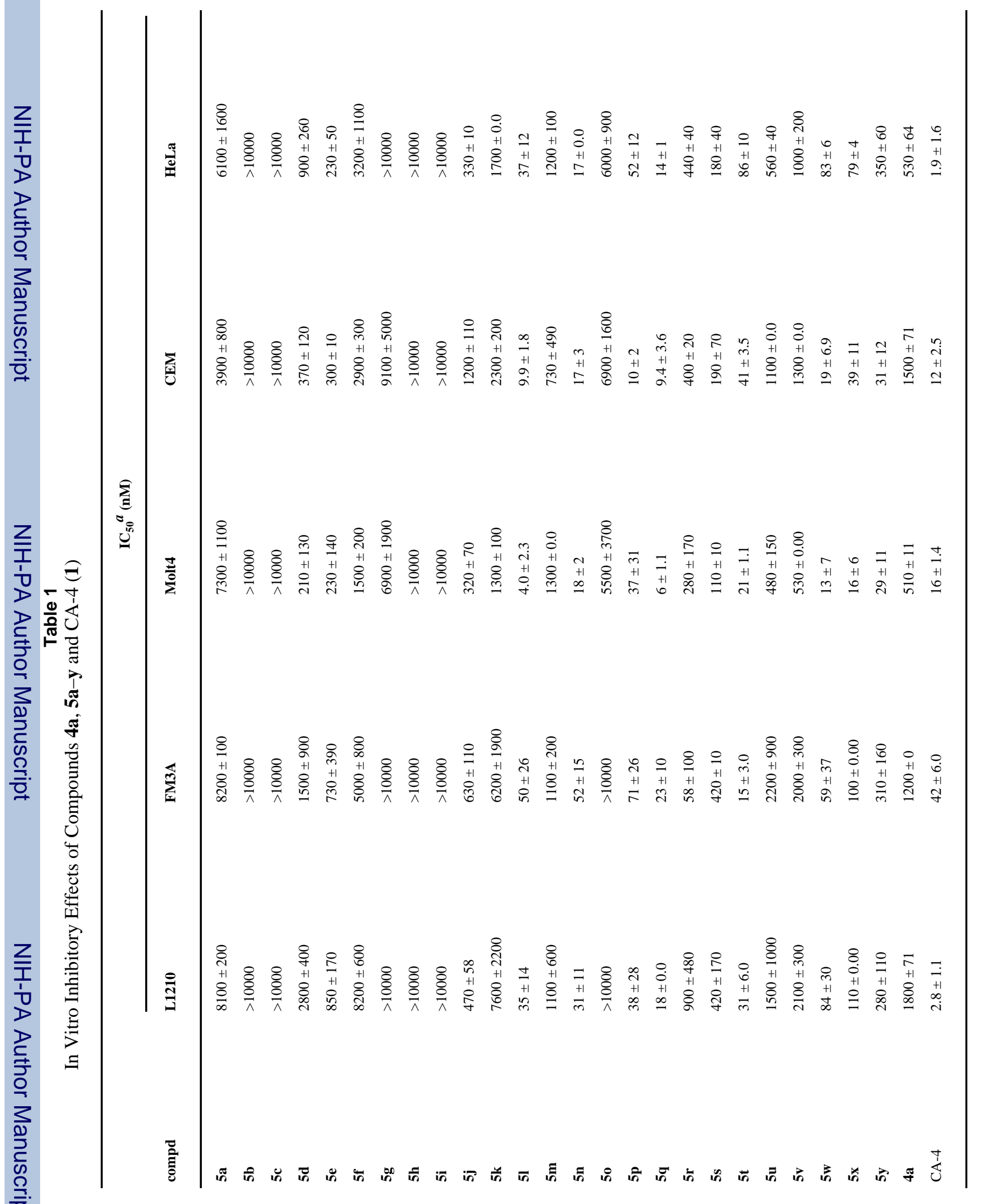


Table 2

Inhibition of Tubulin Polymerization and Colchicine Binding by Compounds 4a, 5l, 5n, 5p-q, 5t, 5w, and CA-4

\begin{tabular}{lcc}
\hline $\mathbf{c o m p d}$ & ${\text { tubulin assembly }{ }^{\boldsymbol{a}} \mathbf{I C}_{\mathbf{5 0}} \pm \mathbf{S D}(\boldsymbol{\mu M})}$ & colchicine binding $\boldsymbol{b} \pm \mathbf{S D}^{\boldsymbol{b}}$ \\
\hline $\mathbf{5 a}$ & $8.0 \pm 0.7$ & $35 \pm 2$ \\
$\mathbf{5 f}$ & $3.6 \pm 0.4$ & $43 \pm 2$ \\
$\mathbf{5}$ & $1.4 \pm 0.2$ & $84 \pm 2$ \\
$\mathbf{5 n}$ & $1.4 \pm 0.2$ & $77 \pm 4$ \\
$\mathbf{5 p}$ & $2.8 \pm 0.3$ & $63 \pm 0.2$ \\
$\mathbf{5 q}$ & $2.5 \pm 0.3$ & $75 \pm 2$ \\
$\mathbf{5 t}$ & $0.72 \pm 0.01$ & $87 \pm 1$ \\
$\mathbf{5 w}$ & $1.1 \pm 0.1$ & $89 \pm 2$ \\
$\mathbf{4 a}$ & $4.0 \pm 0.4$ & $58 \pm 3$ \\
CA-4 (1) & $1.4 \pm 0.1$ & $87 \pm 3$ \\
\hline
\end{tabular}

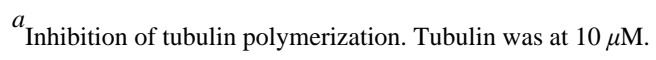

${ }^{b}$ Inhibition of $\left[{ }^{3} \mathrm{H}\right]$ colchicine binding. Tubulin, colchicine, and tested compound were at 1,5 , and $1 \mu \mathrm{M}$, respectively. 